\title{
The energy equivalents of ATP and the energy values of food proteins and fats
}

\author{
BY GEOFFREY LIVESEY \\ Division of Nutrition and Food Quality, ARC Food Research Institute, Colney Lane, \\ Norwich, NR4 7UA
}

(Received 4 March 1983-Accepted 19 July 1983)

\begin{abstract}
1. Heats of combustion and energy equivalents of cytoplasmic ATP have been estimated for glucose, 101 food proteins and 116 food fats based on amino acid and fatty acid composition data from food composition tables and the heats of combustion and energy equivalents of cytoplasmic ATP of each individual amino acid, fatty acid, glycerol and glucose. The isodynamic equivalents of carbohydrate, fat and protein at the biochemical level have been investigated.
\end{abstract}

2. Heats of combustion of food proteins and fats derived from compositional data were within $1 \%$ of published values obtained by calorimetry.

3. Cytoplasmic ATP equivalents for glucose, fat and protein range from $9 \cdot 0$ to $14 \cdot 7,8.6$ to 14.6 and $6 \cdot 4$ to $13.2 \mathrm{~mol}$ cytoplasmic ATP/MJ of metabolizable energy respectively, depending on the choice of mitochondrial proton stoichiometries for these estimations. The range is extended further when considering the level and type of mitochondrial 'uncoupling'.

4. Isobioenergetic relationships between the efficiencies of glucose $(G)$ and fat $(F)(F=1.05 G-0.9)$ and glucose and protein $(P)(P=G(1.02-0.19 f)-(1.8+0.5 f))$ energy conversions (where $f$ is the fraction of protein oxidized via gluconeogenesis) were obtained and were essentially independent of the choice of mitochondrial proton stoichiometry and the level and type of uncoupling of oxidative phosphorylation.

5. Potential errors in previous estimates of ATP yield from protein are shown to be as much as -17.6 to $>118 \%$; accounting for the efficiency of mitochondrial oxidative phosphorylation narrows this to between -7.9 and $17.4 \%$ and accounting for the fraction of protein oxidized via gluconeogenesis limits this further to between -7.9 and $11.1 \%$. Remaining uncertainty is attributed mostly to lack of knowledge about the energy cost of substrate absorption from the gut and transport across cell membranes.

6. Coefficients of variation (cv) in the cytoplasmic ATP yield/g protein and /g protein nitrogen for the 101 food proteins were large $(0.033$ and 0.058 respectively). This is attributed mostly to variation in the metabolizable heats of combustion (cv 0.033 and 0.053 respectively) and to a much smaller extent in the efficiency with which cytoplasmic ATP equivalents are generated/MJ of metabolizable energy (cv 0.01).

7. It is concluded that the current understanding of biochemical energy transduction is sufficient to permit only a crude estimate of the energy equivalents of cytoplasmic ATP but that these equivalents vary by less than $5 \%$ between both different food proteins and different food fats. Isobioenergetic equivalents for carbohydrates, fats and protein which could be applied to modify the Atwater conversion factors are possible but require first an accurate quantification of the energy equivalent of cytoplasmic ATP for glucose in vivo, and an indication that oxidative phosphorylation is similarly efficient in different individuals.

Classically, food energy values are obtained by application of Atwater conversion factors for carbohydrates, fats and proteins or, alternatively, by measurements using bomb calorimetry (see Merrill \& Watt, 1955; Paul \& Southgate, 1978). There have been relatively few attempts at estimating the biochemically available energy in foods probably because of the vast book-keeping exercise involved and because some of the inherent assumptions raise questions regarding the validity and utility of such estimates. Nevertheless, expressing metabolizable energy on a biochemical basis, e.g. as an amount of ATP synthesized/unit of food oxidized (Schulz, 1975), is a useful concept and, rather than being a mere academic exercise, is a prerequisite to the evaluation of the energy costs of metabolic processes such as protein turnover, carbohydrate storage, fat storage, etc., when these are estimated on theoretical grounds (Hommes et al. 1975; Millward et al. 1976; Flatt, 1977, 1980; Schulz, 1977; Waterlow et al. 1978; Webster et al. 1978; Hommes, 1980; Reeds et al. 1980; Gregg \& Milligan, 1982). Further, it could provide an alternative and possibly improved basis on 
which to estimate food energy values, in particular the protein: energy value (Miller \& Payne, 1961).

The present work was undertaken to evaluate some of the limitations which arise from current uncertainties and gaps in knowledge about the biochemical energy transduction pathways and to illustrate quantitatively how these might affect both the estimation of biochemically available food energy and the isodynamic equivalence of protein, fats and carbohydrates as originally envisaged by Rubner (1902).

It is well established that biochemical energy available to the organism from dietary protein is less than that from an isoenergetic amount of fat or carbohydrate (Krebs, 1964), mainly due to the energy cost of nitrogen excretion as urea (Sallach \& Farhren, 1969). Moreover, the energy available, when expressed as mol ATP/g protein oxidized, varies depending upon the source of the protein (Schulz, 1975). On observing that the number of mol ATP yielded/g protein $\mathrm{N}$ varied considerably between proteins, McGilvery (1979) emphasized the need for estimating protein energy values of individual foods. The precise biochemical energy values obtained are, however, not only affected by the source or composition of the food but are highly dependent on the assumptions made to account for gaps or uncertainties in biochemical knowledge. The major metabolic pathways for the oxidation of food components is not a subject of current controversy. However, the precise proton stoichiometries of mitochondrial oxidative phosphorylation form a grey area in which there has been much effort at clarification but still no agreement (Mitchell \& Moyle, 1968, 1969; Brand et al. 1976a, b; Reynafarje et al. 1976; Alexandre et al. 1978, 1980; Azzone et al. 1978; Vercesi et al. 1978; Alexandre \& Lehninger, 1979; Hinkle \& Yu, 1979; Pozzan et al. $1979 a, b$; Wilkström \& Krab, 1979; Papa et al. 1980a, b; Al-Shawi \& Brand, 1981; Hinkle, 1981). ${ }^{+} \mathrm{H}:$ O stoichiometries for coupling of oxidative phosphorylation at sites $2+3$ in mitochondria have been found to be 4,6 or 8 . For sites $1+2+3,{ }^{+} \mathrm{H}: \mathrm{O}$ stiochiometries have been found to be 6,10 or 12 and ${ }^{+} \mathrm{H}$ : ATP values for the $F_{0}-F_{1}$ ATPase (the site of ATP synthesis) have been found to be either 2 or 3 . Fortunately these authors agree that the ${ }^{+} \mathrm{H}$ :ATP value is unity for the transport of ATP across the inner mitochondrial membrane. Whilst there are some fifty-four combinations of these stoichiometries, not all combinations are possible; six only, which are compatible with experimental observations, are accounted for in the present work. Whereas the above stoichiometries are for tightly coupled mitochondria, there is little evidence showing mitochondria in vivo to be tightly coupled. ${ }^{31}$ Phosphorus nuclear magnetic resonance saturation transfer methods on isolated perfused rat heart and rat brain in vivo, i.e. tissues expected to have highly coupled mitochondria, suggest ADP:O values between 2 and 3.5 (Matthews et al. 1981; Shoubridge et al. 1982). The precise values are difficult to interpret since such ${ }^{31} \mathrm{P}$ nuclear magnetic resonance studies are inherently inaccurate at present. However, evidence shows that mitochondria from brown adipose tissue (Nicholls, 1976, 1982; Nicholls \& Lock, 1981) and other tissues (Skulachev, 1963; Chance, 1970; Ball, 1973) can exhibit uncoupling to varying extents. How these uncertainties and others affect calculations of biochemically available energy from foods, especially food proteins, constitutes a substantial part of the present paper.

\section{METHODS}

\section{Heat energy values}

Metabolites. Heats of combustion of amino acids and other compounds (Hogman, 1962; Ponomarev, 1962; Sober, 1968) are given below together with a calculated value for histidine. The value for histidine is based on the regularity in heat energy values of chemical groups (Janz, 1958) and amino acids (Ponomarev, 1962) and agrees with the Kharasch and Sher formula (see Janz, 1958) for the empirical calculation of heats of combustion. Heats 
of combustion were $(\mathrm{MJ} / \mathrm{mol}$ metabolite): isoleucine $3 \cdot 58$, leucine $3 \cdot 58$, lysine $3 \cdot 68$, methionine $2 \cdot 78$, cysteine $2 \cdot 23$, phenylalanine 4.65 , tyrosine $4 \cdot 44$, threonine $2 \cdot 05$, tryptophan 5.63 , valine 2.92 , arginine $3 \cdot 74$, histidine $3 \cdot 37$, alanine 1.62 , aspartate 1.61 , asparagine 1.93 , glutamate 2.25 , glutamine 2.57 , glycine 0.97 , proline 2.73 , serine 1.45 , urea 0.63 , ammonia $0 \cdot 63$, glycerol $1 \cdot 66$, glucose $2 \cdot 82$, galactose $2 \cdot 81$, fructose $2 \cdot 83$. Heats of combustion of saturated and unsaturated fatty acids of odd and even chain lengths were calculated from the formula $-\Delta \mathrm{Hc}=0.653 n-0.166 d-0.421$, where $n$ is the number of carbon atoms/molecule fatty acid, $d$ is the number of double bonds/fatty acid and $-\Delta \mathrm{Hc}$ is the heat of combustion in $\mathrm{MJ} / \mathrm{mol}$. This formula was derived here from a regression of $-\Delta \mathrm{Hc}$ for $\mathrm{C} 2, \mathrm{C} 3, \mathrm{C} 4, \mathrm{C} 5, \mathrm{C} 6, \mathrm{C} 7, \mathrm{C} 11, \mathrm{C} 14, \mathrm{C} 16$ and $\mathrm{C} 18$ fatty acids (values from Hogman, 1962) against fatty acid chain length (which gave $-\Delta H c=0.653 n-0.421$ ) and corrects for the lower heat of combustion of the corresponding unsaturated fatty acids. This correction was taken to be equivalent to the difference in the heat of combustion of stearic and oleic acids, propionic and acrylic acids, succinic and maleic acids and ethyl and allyl alcohols (mean (SEM): $0.166(0 \cdot 019), n 5)$. The formulae compare favourably with the Kharasch and Sher formula and that for saturated fatty acids (Adriaanse et al. 1965).

Food proteins. Heats of combustion of food proteins are based on the amino acid compositions of foods in McCance \& Widdowson's 'The Composition of Foods' (Paul \& Southgate, 1978) and assume that half the aspartate and glutamate is in the amide form. This is consistent with the average amino acid composition for specific proteins of animal and vegetable origin (Croft, 1973) and errors arising from this assumption are found here to be negligible. The heats of combustion of food proteins were determined as $\mathrm{MJ} / \mathrm{g}$ food $\mathrm{N}$ according to the expression:

$$
-\Delta \mathrm{Hc} \text { (protein) }=\sum_{\alpha \alpha_{1}}^{\alpha \alpha_{20}} 10^{-3} \frac{B}{C} \times A,
$$

where $B$ is $\mathrm{mg}$ amino acid/ $\mathrm{g}$ food $\mathrm{N}$ (from food tables), $A$ is $-\Delta \mathrm{Hc}$ for the corresponding amino acid, $C$ is molecular weight of the corresponding amino acid and $\Sigma_{\alpha \alpha_{1}}^{\alpha \alpha_{20}}$ is the sum for each of the twenty amino acids. This formula does not account for the heat of hydrolysis of the peptide bond which amounts to less than $0.3 \%$ of the heat energy of proteins, being equal to only $8 \times 10^{-3} \mathrm{MJ} /$ peptide bond (Rawitscher et al. 1961).

The potential metabolizable energy in the food protein was taken to be the difference in the heat of combustion of the food protein and that for the end-products of metabolism, urea and ammonia; these products have the same heat of combustion $(15 \mathrm{MJ} / \mathrm{g} \mathrm{N})$ so the above difference is independent of the distribution of $\mathrm{N}$ between them. $-\Delta \mathrm{Hc}$ for the endproducts was expressed as $\mathrm{MJ} / \mathrm{g}$ food $\mathrm{N}$ and calculated as follows:

$$
-\Delta \mathrm{Hc} \text { (ammonia, urea) }=\sum_{\alpha \alpha_{1}}^{\alpha \alpha_{20}} 0.32 \times 10^{3} \frac{B}{C} \times D,
$$

in which $B$ and $C$ are as defined previously, $D$ is the number of $\mathrm{N}$ atoms/amino acid and the constant in the equation is $-\Delta \mathrm{Hc}$ for ammonia, or half the $-\Delta \mathrm{Hc}$ for urea (i.e. $0.32 \mathrm{MJ} / \mathrm{mol}$ ).

Protein energy values $(\mathrm{MJ} / \mathrm{g}$ food $\mathrm{N}$ ) were, for comparison with values in the literature, converted to $\mathrm{MJ} / \mathrm{g}$ protein by dividing by the sum weight of amino acid residues in the protein/g food $\mathrm{N}$.

Food fats. Heats of combustion of fats in foods were computed using the fatty acid composition data in the food tables (Paul \& Southgate, 1978) on the basis that all fatty acids were present in triglyceride form. The energy contribution of cholesterol and the ionic moeity of phospholipid was neglected since this contributes only a small proportion of 
dietary energy. Heats of combustion of food triglycerides were expressed as $\mathrm{MJ} / 100 \mathrm{~g}$ food fatty acid according to the formula:

$$
-\Delta \mathrm{Hc} \text { (triglyceride) }=1.66 \sum_{\mathrm{FA}_{1}}^{\mathrm{FA}_{\infty}} \frac{B^{\prime}}{3 D}+\sum_{\mathrm{FA}_{1}}^{\mathrm{FA}_{\infty}} \frac{B^{\prime}}{D} I,
$$

in which $B^{\prime}$ is $\mathrm{g}$ fatty acid (FA) $/ 100 \mathrm{~g}$ food total fatty acid (from the food tables), $D$ is molecular weight of the corresponding fatty acid and $I$ is $-\Delta \mathrm{Hc}$ of the corresponding fatty acid. The constant 1.66 is $-\Delta \mathrm{Hc}(\mathrm{MJ} / \mathrm{mol})$ for glycerol. The potential metabolizable energy of the food triglycerides was taken to be equal to $-\Delta \mathrm{Hc}$ (triglycerides). Heats of hydrolysis of the triester linkages were neglected as this amounts to less than $0.1 \%$ of the heat energy of tryglycerides, being only approximately $2 \times 10^{-3} \mathrm{MJ} /$ ester bond (Adriaanse et al. 1965).

For comparison with literature values, $\mathrm{MJ}$ triglyceride $/ 100 \mathrm{~g}$ food fatty acid were divided by the calculated weight of the triglyceride $/ 100 \mathrm{~g}$ food fatty acid to give $\mathrm{MJ} / \mathrm{g}$ fat.

\section{Biochemical energy values}

Metabolic pathways for the oxidation of monosaccharides, amino acids, fatty acids and glycerol used in the computation of ATP yields were direct, i.e. not via the storage forms glycogen, fat and protein. Oxidation of protein via gluconeogenesis was considered as an option. Several assumptions were made: ATP expenditure within the mitochondrial matrix, except for substrate activation during oxidation, is negligible by comparison with extra mitochondrial ATP utilization; metabolic stoichiometries represent the major metabolic pathways; glutamate transport out of mitochondria during urea synthesis is balanced by citrulline transport into mitochondria in order to produce no net effect on the mitochondrial proton electrochemical gradient (see Whittaker \& Danks, 1978; Nicholls, 1982).

ATP yields with coupled mitochondria. For each amino acid, fatty acid, glycerol and monosaccharide the potential net cytoplasmic ATP yield was computed as follows:

$$
\begin{aligned}
& \text { cytoplasmic ATP yield }=n_{1} \mathrm{ATP}_{\text {cyt }}+n_{2} \mathrm{ATP}_{\text {mit }} \\
& +n_{3} \mathrm{NADH}_{\mathrm{cyt}}+n_{4} \mathrm{NADH}_{\mathrm{mit}}+n_{5} \mathrm{FADH}_{2}
\end{aligned}
$$

where $n_{1}, n_{2}, n_{3}, n_{4}$ and $n_{5}$ are mol cytoplasmic ATP, mitochondrial ATP, cytoplasmic $\mathrm{NADH}$, mitochondrial NADH and $\mathrm{FADH} \mathrm{H}_{2}$ produced (net) respectively during the oxidation of 1 mol substrate. $\mathrm{ATP}_{\mathrm{cyt}}, \mathrm{ATP}_{\mathrm{mit}}, \mathrm{NADH}_{\mathrm{cyt}}, \mathrm{NADH}_{\mathrm{mit}}$ and $\mathrm{FADH}_{2}$ are the cytoplasmic ATP equivalents of the corresponding 'high energy' compounds. In all cases ATP $_{\text {eyt }}$ was rigidly defined as equal to 1 . The cytoplasmic ATP equivalents of other 'high energy' compounds were computed in accordance with the ${ }^{+} \mathrm{H}: \mathrm{O}$ and the ${ }^{+} \mathrm{H}$ : ATP values for the electron transport complexes, $F_{1}-F_{0}$ ATPase and ATP transport across the mitochondrial inner membrane (see Table 1). The values $n_{1}, n_{2}, n_{3}, n_{4}$ and $n_{5}$ were varied in accordance with the oxidative pathway under consideration (e.g. direct oxidation or indirect oxidation of protein via gluconeogenesis), the considered energy cost of substrate absorption, the extent of involvement of the $\alpha$-glycerophosphate shuttle in the transfer of reducing equivalents into the mitochondria, etc. NADPH does not appear in this formula; its utilization during oxidation of phenylalanine, tyrosine and tryptophan was balanced by an equal production of NADPH via malic enzyme. This seemed preferable since the transhydrogenase catalysing the formation of NADPH appears not to be linked to ATP utilization but to be driven by a proton electrochemical gradient (Rydstrom et al. 1981).

ATP yields with uncoupled mitochondria. Two types of uncoupling are considered, proton leakage or short circuiting (Nicholls, 1976, 1982; Nicholls \& Lock, 1981), which uncouples mitochondrial proton re-entry from $F_{0}-F_{1}$ ATPase activity, and uncoupled proton translocation, which disconnects electron transfer from proton ejection (Skulachev, 1963; 
Table 1. Coupling ratios and cytoplasmic ATP equivalents of 'high energy' compounds and substrates for coupled mitochondrial oxidative phosphorylation

\begin{tabular}{|c|c|c|c|c|c|c|c|}
\hline & $\boldsymbol{A}$ & $B$ & $C$ & $D$ & $E$ & $F$ & $G$ \\
\hline & \multicolumn{7}{|c|}{ Coupling ratios } \\
\hline (a) $\mathrm{H}^{+}: \mathrm{O}$ succinate & 8 & 8 & 6 & 6 & 6 & 4 & 4 \\
\hline (b) $\mathrm{H}^{+}: \mathrm{O} \mathrm{NADH}_{\mathrm{mit}}$ & 10 & 12 & 9 & 8 & 10 & 6 & 6 \\
\hline (c) $\mathrm{H}^{+}$: ATP $F_{1}-F_{0}$ ATPase & 2 & 3 & 2 & 2 & 3 & 2 & 2 \\
\hline (d) $\mathrm{H}^{+}$: ATP transport & 1 & 1 & 1 & 1 & 1 & 1 & 0 \\
\hline (e) Succinate: $\mathrm{ATP}_{\mathrm{cyt}}(\mathrm{P}: \mathrm{O}$ succinate) & $2 \cdot 67$ & $2 \cdot 00$ & $2 \cdot 00$ & 2.00 & $1 \cdot 50$ & $1 \cdot 33$ & 2 \\
\hline (f) $\mathrm{NADH}_{\mathrm{mit}}$ : $\mathrm{ATP}_{\mathrm{cyt}}\left(\mathrm{P}: \mathrm{O} \mathrm{NADH}_{\mathrm{mit}}\right)$ & $3 \cdot 00$ & 3.00 & $3 \cdot 00$ & $2 \cdot 67$ & $2 \cdot 50$ & 2.00 & 3 \\
\hline (g) $\mathrm{NADH}_{\text {eyt }}$ : ATP $_{\text {eyt }}$ & $3 \cdot 00$ & $2 \cdot 75$ & 2.67 & $2 \cdot 33$ & $2 \cdot 25$ & 1.67 & 3 \\
\hline \multirow[t]{2}{*}{ (h) $\mathrm{ATP}_{\mathrm{mit}}: \mathrm{ATP}_{\mathrm{eyt}}$} & 0.67 & $0 \cdot 75$ & 0.67 & 0.67 & 0.75 & 0.67 & 1 \\
\hline & \multicolumn{7}{|c|}{ Cytoplasmic ATP equivalents } \\
\hline (i) cyt $\mathrm{ATP} / \mathrm{mol}$ glucose* & $41 \cdot 3$ & $37 \cdot 0$ & $36 \cdot 7$ & $33 \cdot 4$ & $31 \cdot 0$ & $25 \cdot 3$ & 38 \\
\hline (j) cyt $\mathrm{ATP} / \mathrm{ME}$ glucose & $14 \cdot 7$ & $13 \cdot 1$ & $13 \cdot 0$ & 11.9 & $11 \cdot 0$ & $9 \cdot 0$ & $13 \cdot 5$ \\
\hline (k) cyt ATP/ME fat $\dagger$ & $14 \cdot 6$ & $12 \cdot 7$ & $12 \cdot 7$ & 11.6 & $10 \cdot 4$ & 8.6 & - \\
\hline (l) cyt ATP/ME protein $\dagger$ & $13 \cdot 2$ & $11 \cdot 5$ & $11 \cdot 5$ & $10 \cdot 4$ & $9 \cdot 3$ & $7 \cdot 4$ & - \\
\hline $\begin{array}{l}\text { (m) cyt ATP/ME protein } \dagger \\
\text { (oxidation via glucose) }\end{array}$ & $12 \cdot 6$ & $10 \cdot 9$ & $9 \cdot 9$ & $9 \cdot 8$ & $8 \cdot 6$ & $6 \cdot 4$ & - \\
\hline
\end{tabular}

Columns $A-G$ are possible coupling ratios and cytoplasmic ATP equivalents; $G$, originally proposed by Mitchell \& Moyle $(1967 a, b 1968)$, is now recognized as unlikely and is not used in the computations. $B, C, E, F$ are for coupling ratios proposed by Reynafarje et al. (1976), Nicholls (1982), Hinkle \& Yu (1979) and Hinkle (1981) respectively; $A$ and $D$ are other theoretically possible ratios (see text); $e, f, g, h$ are derived from $a, b, c, d$ by calculation: $e=a /(c+d), f=b /(c+d), g=(b-d) /(c+d), h=c /(c+d) ; i, j, k, l, m$ were computed as described in the methods section.

ME, metabolizable energy (MJ). P:O, phosphate: oxygen ratio.

* ATP $_{\text {eyt }}$ is rigidly defined as unity (see text) whereas cyt ATP is the number of cytoplasmic ATP equivalents.

+ Values are means for 116 food fats.

$\$$ Values are means for 101 food proteins.

Chance, 1970; Ball, 1973). The latter affects the ${ }^{+} \mathrm{H}$ : O stoichiometry at sites $2+3$ only. For coupled mitochondria coupling ratios are as given in Table 1. For uncoupled mitochondria the coupling ratios were as follows:

$$
\begin{aligned}
& \text { FADH }_{2} \text { (succinate: cytoplasmic ATP) }=\left[a\left(1-U_{1}\right)\left(1-U_{2}\right)\right] /(c+d) \\
& \mathrm{NADH}_{\text {mit }}=\left[(b-a)\left(1-U_{1}\right)+a\left(1-U_{1}\right)\left(1-U_{2}\right)\right] /(c+d) \\
& \mathrm{NADH}_{\text {cyt }}=\left[(b-a-1)\left(1-U_{1}\right)+a\left(1-U_{1}\right)\left(1-U_{2}\right)\right] /(c+d)
\end{aligned}
$$

where $a$ and $b$ are as derived in Table $1, U_{1}$ and $U_{2}$ are the fractional uncoupling by proton leakage or short circuiting and uncoupled proton translocation at sites $2+3$ respectively, and the constant in the last equation, -1 , accounts for the electrogenic proton translocation associated with glutamate entry into mitochondria in the Borst cycle (Nicholls, 1982). When reducing equivalents were considered to be transferred via the $\alpha$-glycerphosphate shuttle then the cytoplasmic ATP equivalent of $\mathrm{NADH}_{\text {cyt }}$ was made equal to that for $\mathrm{FADH}_{2}$.

ATP yields for proteins, fats and carbohydrates. These were calculated in the same way as the heats of combustion of proteins and fats with substitution in the appropriate formula of $-\Delta \mathrm{Hc}$ values with the potential net cytoplasmic ATP yield for the individual amino acids, fatty acids and glycerol.

Carbohydrates, as monosaccharides in foods, are mostly glucose, fructose, galactose and ribose. Ribose represents a negligible contribution to the carbohydrate energy in foods. Values of $n_{1}, n_{2}, n_{3}, n_{4}$ and $n_{5}$ and $-\Delta \mathrm{Hc}$ are the same for glucose, fructose and galactose (not accounting for potential differences in the energy costs of absorption which would affect 
$n_{1}$ ). Hence the cytoplasmic ATP yield and $-\Delta H c$, for glucose, were taken, being as typical of food carbohydrate as monosaccharide.

Available biochemical energy and metabolizable energy. In this study the available biochemical energy is expressed as the potential net yield of cytoplasmic ATP in mol/MJ of metabolizable energy in protein, fat or glucose. Metabolizable energy values, calculated as above, assume absorption of food components in equal proportions to their presence in food. This is not so of available biochemical energy which requires only that absorbed and non-absorbed nutrients have similar available biochemical energies (had the latter been absorbed).

Specific dynamic action. This is defined here as the extra energy required for the synthesis of 1 mol cytoplasmic ATP when protein (or fat) is oxidized in place of glucose, in keeping with the definition of specific dynamic action given by Krebs (1964). This is a working definition and in no way implies that the thermic effect of food observed in the post-prandial period is due to the replacement of glucose as an energy source by protein (or fat) or that an increased rate of protein synthesis is not a major contributor to the thermic effect of food (see Ashworth, 1969; Garrow \& Hawes, 1972; Pittet et al. 1974), or that other factors are of no importance in diet-induced thermogenesis (Stirling \& Stock, 1968).

\section{RESULTS AND DISCUSSION}

The energy equivalents of $A T P$

The yield of ATP from an oxidizable substrate is highly dependent on the designated cytoplasmic ATP equivalents of other intermediary 'high-energy' compounds as illustrated in Table 1 . The proton stoichiometries shown by $B, C, E$ and $F$ (Table 1 ) are values previously proposed and cited in the literature (see Table 3,p. 20). Those of $A$ and $D$ (Table 1) are possible combinations of coupling ratios based on the range of proton stoichiometries given in the Introduction and the range of published phosphate:oxygen $(\mathrm{P}: \mathrm{O})$ values (see Hinkle \& Yu, 1979) and, being difficult to exclude as highly improbable, were included for completeness. The range of values for the biochemically available energy (mol cytoplasmic ATP/MJ metabolizable substrate) for glucose, protein (mean of 101 food proteins) and fats (mean of 116 food fats) varies considerably from one stoichiometry to another. These values are for tightly coupled mitochondria so the range is narrower than conceived when considering mitochondria in vivo and varying levels of coupling may be exhibited (see below). Some previous attempts at deriving the energy equivalents of ATP gave values (ATP/MJ metabolizable energy) of $12.8,12.9$ and 9.2 for glucose, 12.9 and 12.8 for fat and 11.7 and 9.3 for protein (see Schulz, 1975; Flatt, 1980; Hommes, 1980) which fall well within the range given in Table 1. It is clearly possible to find evidence to back any of a wide range of energy equivalents for ATP for a given substrate and this surely restricts the application of the 'Atkinson (1971) metabolic pricing system' (see Hommes, 1980).

\section{Isobioenergetic equivalents of nutrients}

The question remains, however, as to whether Rubner's (1902) concept of the isodynamic equivalence of nutrients is valid at the level of net cytoplasmic ATP synthesis. This is of importance since it questions the basis of the Atwater method for the estimation of the energy values of foods. The question was examined by determining how the cytoplasmic ATP equivalents of food proteins and fats vary as the estimated glucose (typical of carbohydrate as monosaccharide) ATP equivalent changes in accordance with the different values for the coupling ratios (Table 1) in both coupled and uncoupled systems.

Fig. 1 shows linear relationships between both fat and protein energy and glucose energy when expressed as mol cytoplasmic ATP/MJ metabolizable energy. The position of the curve for protein is lower when the pathway for oxidation is via gluconeogenesis than when 


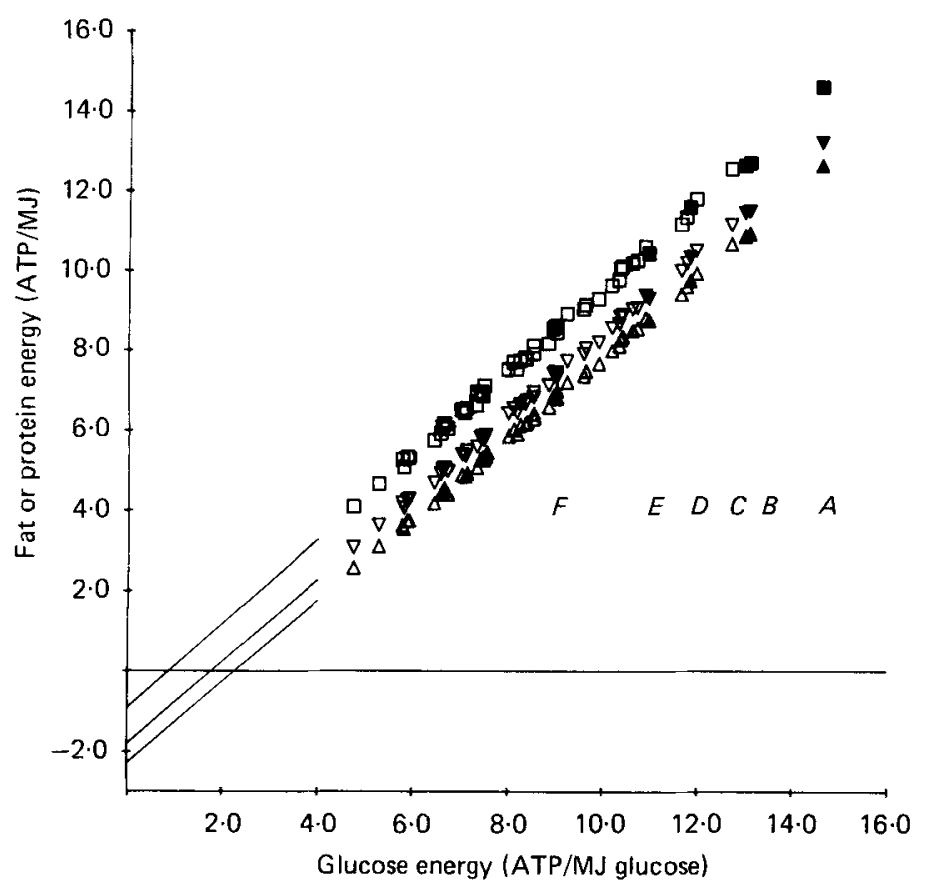

Fig. 1. Efficiencies of oxidation of fat and protein relative to that for glucose. The fifty-four data symbols on each curve represent energy values (mol cytoplasmic ATP/MJ metabolizable energy) for each of the six proton stoichiometries $(A-F$, Table 1$)$ at three levels of proton leakage $\left(U_{1},=0.0,0.2\right.$ or 0.4$)$ and uncoupling of electron transport from proton ejection $\left(U_{2}=0.0,0.17\right.$ or 0.33 ). $\square$, Fat (mean of 116 food fats); $\nabla$, protein oxidation directly (mean of 101 food proteins); $\triangle$, protein oxidation via glucose (mean of 101 food proteins). $\square, \boldsymbol{\nabla}, \boldsymbol{\Delta}$, Energy values for tightly coupled mitochondria (i.e. $U_{1}=0 \cdot 0$, $U_{2}=0.0$ ).

oxidation is direct. The fifty-four data points for each curve (Fig. 1) are for the available biochemical energies based on each of the six $(A-F)$ proton stoichiometries (Table 1) at varying levels of mitochondrial uncoupling $\left(U_{1}=0.0,0 \cdot 2\right.$ and $0.4 ; U_{2}=0.0,0.17$ and 0.33 ; nine levels in all). The ranges of $U_{1}$ and $U_{2}$ were restricted since it is unlikely that the 'average' mitochondrion in vivo is extensively uncoupled. All the results fall on curves (Fig. 1) such that each relationship is broadly independent of the precise proton stoichiometries and the type and extent of uncoupling of mitochondrial oxidative phosphorylation.

The isobioenergetic relationships shown in Fig. 1 are described by the following equations: $F=1.05 G-0.9, P=1.02 G-1.8, P^{\prime}=1.01 G-2 \cdot 3$, where $F$ is available biochemical energy in fat (cytoplasmic ATP/MJ), $G$ is available biochemical energy in glucose (cytoplasmic ATP/MJ), $P$ and $P^{\prime}$ are the available biochemical energies (cytoplasmic ATP/metabolizable MJ) in protein oxidized directly and via glucose respectively. Knowledge of the cytoplasmic ATP equivalent of glucose in vivo would permit an estimation of fat and protein energy using these equations without prior knowledge of the precise coupling ratio or the type and level of mitochondrial uncoupling. If the distribution of protein oxidation between direct and indirect oxidations were known, the above equations for protein would combine to produce $P=G(1.02-0.01 f)-(1.8+0.5 f)$, where $f$ is the fraction of protein oxidized via gluconeogenesis.

Fig. 1 is, however, somewhat insensitive to the differences in cytoplasmic equivalents of fats and proteins relative to that for glucose for the varying proton stoichiometries $(A-F)$ and extent and type of uncoupling. This is better illustrated by Fig. 2. For fats, two clusters 


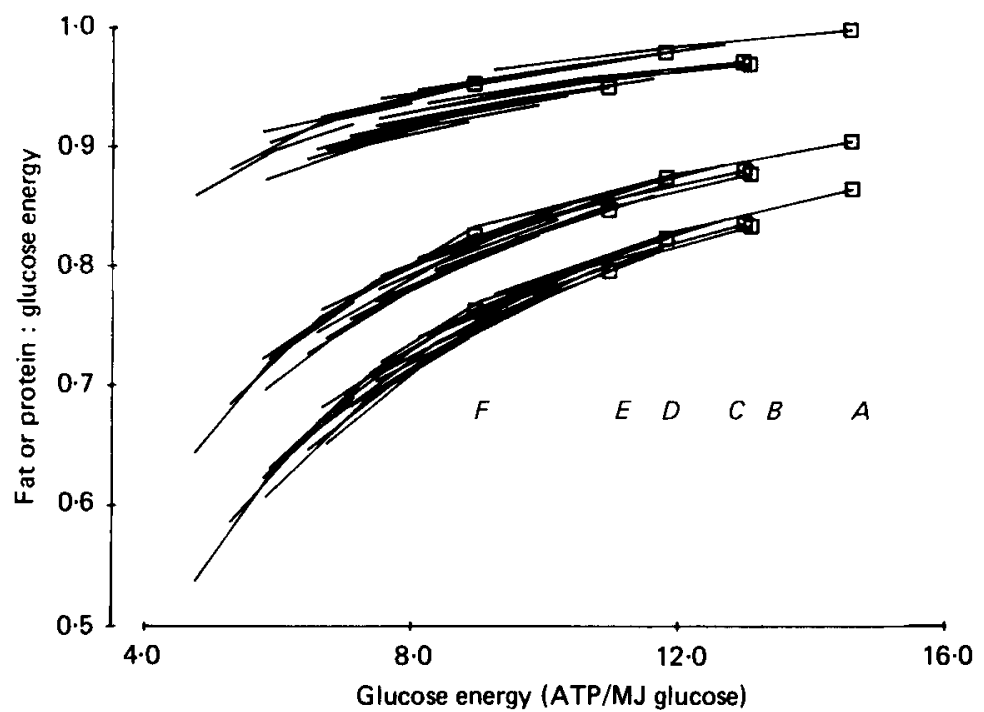

Fig. 2. Change in the efficiencies of oxidation of fat and protein relative to that for glucose. Three groups of curves are shown which represent (mol cytoplasmic ATP/MJ metabolizable energy in fat or protein per cytoplasmic ATP/MJ glucose): upper, fat: glucose; middle, protein (directly oxidized): glucose; lower, protein (oxidized via glucose) : glucose energy. Each group is composed of eighteen curves: three curves $\left(U_{1}=0.0,0.2\right.$ and 0.4$)$ are drawn for each of the six proton stoichiometries $(A-F$, Table 1$)$. Individual curves join co-ordinates at three levels of $U_{2}(0 \cdot 0,0 \cdot 17$ and $0 \cdot 33) .\left(U_{1}\right.$ and $U_{2}$ are the fractional uncoupling by proton leakage or short circuiting and uncoupled proton translocation respectively.) The six data symbols in each group are energy values for each of the six proton stoichiometries $(A-F)$ in tightly coupled systems (i.e. $U_{1}=0 \cdot 0, U_{2}=0 \cdot 0$ ).

of curves are apparent which correspond to proton stoichiometries $A, D$ and $F$ and $B, C$ and $D$. Close inspection of the curves in Fig. 2 for the protein: glucose energy values also shows these two clusters but with slight overlap. Thus knowledge of the precise proton stoichiometry would lead to some, although only small, improvements in the estimation of the fat or protein: glucose energy values (approximately $2 \%$ for protein and $4 \%$ for fat). It is apparent from Fig. 2 that Rubner's (1902) concept of the isodynamic equivalence of nutrients can hold at the biochemical level only when the extent of coupling of mitochondrial oxidative phosphorylation changes little and, as shown for protein, that flux through metabolic routes having differing efficiencies of energy conversion is relatively constant. Further, Fig. 2 shows that the biochemical energy values of fats and glucose, which have previously been considered to be similar (Schulz, 1975; Flatt, 1980; Hommes, 1980) can differ at low efficiencies for oxidative phosphorylation.

\section{Potential errors in the estimate of biochemically available energy from protein}

The precise proton stoichiometries used in the calculation of protein energy values and the type and level of uncoupling were shown to have only small $(<2 \%)$ effects on the position of the regression curve relating the efficiency of protein oxidation (mol cytoplasmic ATP/MJ metabolizable energy in protein) to the efficiency of glucose oxidation (mol cytoplasmic ATP/MJ glucose). In the analysis of potential errors (Table 2) the energy value for glucose has been limited to the range 7-15 mol cytoplasmic ATP/MJ; below 7, the direct oxidation of protein is associated with a specific dynamic action for the average food proteins which exceeds $35 \%$ and is considered too improbable to merit further consideration. Combinations of assumptions inherent in the computation of protein energy value $>35 \%$ for 
glucose energy values above $7 \mathrm{~mol}$ cytoplasmic ATP/MJ are included in Table 2 but are similarly considered improbable combinations of conditions.

For the analysis of errors, two bases for comparisons have been used (Table 2): Base 1 relates to errors involved if the glucose energy value in cytoplasmic ATP/MJ were known and Base 2 relates to errors incurred by assuming that mitochondria in vivo are tightly coupled and the $\mathrm{P}: \mathrm{O}$ value for succinate and $\mathrm{NADH}_{\text {mit }}$ to be 2 and 3 respectively. Base 2 comprises the conditions for which previous attempts were made to estimate the energy equivalent of ATP for protein (Krebs, 1964; Schulz, 1975; Flatt, 1977, 1980) and for which the energy equivalent of cytoplasmic ATP for glucose oxidation is $13 \mathrm{ATP} / \mathrm{MJ}$.

New regression curves were computed which accounted for the assumptions listed in the first column of Table 2 . The errors incurred were determined by comparison of the new regression equation with the equations which match the curves in Fig. 1. (The arithmetic involved in the calculation of these errors is set out in Table 2.) The results (Table 2) show that for all the combinations of assumptions made and for which specific dynamic action for proteins was less than $35 \%$, large potential errors may be incurred by assuming conditions which give a glucose energy value of $13 \mathrm{ATP} / \mathrm{MJ}$; errors range from -17.6 to $>118 \%$ (Table 2). Knowledge of the precise glucose energy value (cytoplasmic ATP/MJ) would limit these errors to between -7.9 and $17.4 \%$ and, accounting for the extent to which protein is oxidized via gluconeogensis, would further limit the errors to between -7.9 and $11.1 \%$. The remaining error is the result of uncertainty in the energy cost of absorption of substrate from the gut plus that associated with translocaton across other membranes, if this is considered within the energy costs applied in the calculations. While the effects of recycling of $\mathrm{N}$ via ureolysis and the incomplete incorporation of $\mathrm{N}$ into urea have been separately examined (Table 2), it is probable that the extent of ureolysis is approximately equal to the rate of ammonia excretion (Walser, 1981) so that this source of error, although difficult to predict precisely, will be small. Furthermore, the error limits of -7.9 to $11 \cdot 1 \%$ do not account for the small differences $(2 \%)$ in the energy values predicted by the various proton stoichiometries $(A-F$, Table 1$)$. Hence, provided that the extent of protein oxidized via gluconeogenesis and the efficiency of glucose oxidation in vivo are adequately accounted for, it is probable that the energy value of protein can be estimated to within $15 \%$ of the value in vivo.

Calculations of the specific dynamic action of proteins is subject to great errors, as shown in Table 3. Hence, previous estimates (e.g. Krebs, 1964; Flatt, 1977, 1980) can only be regarded, at best, as 'very approximate'.

\section{Heats of combustion and available biochemical energy from food proteins and fats}

Heats of combustion (gross energy) of beef, mutton, egg albumin, egg yolk and milk protein, derived here from the amino acid composition data, were not significantly different from values obtained by direct determination (Merrill \& Watt, 1955) showing a mean (and SD) difference of $0.3(1 \cdot 7) \%(n 5)$ between the two methods. For the 101 proteins examined, the mean (and SD) gross heat of combustion, derived from the composition data, was 23.4 $(0.6) \mathrm{kJ} / \mathrm{g}$ and ranged from 21.0 (apricot protein) to 24.6 (yoghurt protein). Gross heats of combustion for the nitrogenous end-products, ammonia and urea, varied little between the 101 proteins with a range of $3 \cdot 6-4 \cdot 3 \mathrm{~kJ} / \mathrm{g}$ protein with a mean (and SD) of $4 \cdot 0(0 \cdot 2)$. Assuming amino acids to be absorbed in the gut in equal proportion to their presence in the food, the mean (and SD) metabolizable energy was $19 \cdot 4(0 \cdot 6) \mathrm{kJ} / \mathrm{g}$ protein $(n 101)$. Gross energy and metabolizable energy for each of the food groups in the food composition tables are given in Table 3. Milk and egg proteins were found to be richer in metabolizable energy than the average for all proteins ( 7 and $3 \%$ respectively), while fruit and nut proteins were relatively poor $(-7$ and $-3 \%$ respectively). 
Table 2. Differences in estimated protein energy values arising from some biochemical uncertainties and the associated specific dynamic action (SDA)

\begin{tabular}{|c|c|c|c|c|c|c|}
\hline Glucose energy $(G ;$ ATP $/ \mathrm{MJ}) \ldots$ & & 7 & 9 & 11 & 13 & 15 \\
\hline $\begin{array}{l}\text { Direct protein oxidation (differenc } \\
\left(P_{2}=1 \cdot 017 G-1 \cdot 80\right)\end{array}$ & $\begin{array}{l}\text { rom } P_{1}= \\
\text { Base } 1 \\
\text { Base } 2 \\
\text { SDA }\end{array}$ & $\begin{array}{c}17 G-1 \\
0 \cdot 0 \\
114 \cdot 7 \\
31 \cdot 6\end{array}$ & $\begin{array}{r}0 \cdot 0 \\
55 \cdot 3 \\
22 \cdot 4\end{array}$ & $\begin{array}{r}0 \cdot 0 \\
21 \cdot 0 \\
12 \cdot 8\end{array}$ & $\begin{array}{r}0.0 \\
0.0 \\
13 \cdot 8\end{array}$ & $\begin{array}{r}0 \cdot 0 \\
-15 \cdot 1 \\
11 \cdot 5\end{array}$ \\
\hline $\begin{array}{l}\text { Oxidation via } \\
\text { glucogenesis } \\
\left(P_{2}=1 \cdot 012 G-2 \cdot 29\right)\end{array}$ & $\begin{array}{l}\text { Base } 1 \\
\text { Base } 2 \\
\text { SDA }\end{array}$ & $\begin{array}{r}11 \cdot 0 \S \\
138 \cdot 2 \S \\
46 \cdot 0 \S\end{array}$ & $\begin{array}{r}7 \cdot 8 \\
67 \cdot 5 \\
32 \cdot 0\end{array}$ & $\begin{array}{r}6 \cdot 1 \\
29 \cdot 1 \\
24 \cdot 4\end{array}$ & $\begin{array}{r}5 \cdot 1 \\
5 \cdot 1 \\
19 \cdot 6\end{array}$ & $\begin{array}{r}4 \cdot 3 \\
11 \cdot 4 \\
16 \cdot 3\end{array}$ \\
\hline $\begin{array}{l}80 \% \text { Urea synthesis* } \\
\left(P_{2}=1 \cdot 058 G-2 \cdot 00\right)\end{array}$ & $\begin{array}{l}\text { Base } 1 \\
\text { Base } 2 \\
\text { SDA }\end{array}$ & $\begin{array}{r}-1 \cdot 6 \\
111 \cdot 2 \\
29 \cdot 5\end{array}$ & $\begin{array}{r}-2 \cdot 2 \\
51 \cdot 8 \\
19 \cdot 6\end{array}$ & $\begin{array}{r}-2 \cdot 6 \\
18 \cdot 5 \\
14 \cdot 1\end{array}$ & $\begin{array}{r}-2 \cdot 8 \\
-2 \cdot 8 \\
10 \cdot 6\end{array}$ & $\begin{array}{r}-3 \cdot 0 \\
-17 \cdot 7 \\
8 \cdot 1\end{array}$ \\
\hline $\begin{array}{c}120 \% \text { Urea synthesis } \dagger \\
\left(P_{2}=1 \cdot 045 G-2 \cdot 55\right)\end{array}$ & $\begin{array}{l}\text { Base } 1 \\
\text { Base } 2 \\
\text { SDA }\end{array}$ & $\begin{array}{r}11.6 \$ \\
139.7 \S \\
46.9 \S\end{array}$ & $\begin{array}{r}7 \cdot 3 \\
66 \cdot 6 \\
31 \cdot 3\end{array}$ & $\begin{array}{r}4 \cdot 9 \\
27 \cdot 7 \\
22 \cdot 9\end{array}$ & $\begin{array}{r}3 \cdot 4 \\
3.4 \\
17.8\end{array}$ & $\begin{array}{r}2 \cdot 5 \\
-12 \cdot 9 \\
14 \cdot 2\end{array}$ \\
\hline $\begin{array}{l}\text { Absorption cost }+: \\
\text { amino acid } 2 \text { ATP } / \mathrm{mol}+ \\
\text { glucose } 0.5 \mathrm{ATP} / \mathrm{mol} \\
\left(P_{2}=1.011 G-1.84\right)\end{array}$ & $\begin{array}{l}\text { Base } 1 \\
\text { Base } 2 \\
\text { SDA }\end{array}$ & $\begin{array}{c}1 \cdot 6 \\
118 \cdot 0 \| \\
33 \cdot 7\end{array}$ & $\begin{array}{r}1 \cdot 3 \\
57 \cdot 3 \\
24 \cdot 0\end{array}$ & $\begin{array}{r}1 \cdot 1 \\
23 \cdot 0 \\
18 \cdot 5\end{array}$ & $\begin{array}{r}1.0 \\
1.0 \\
15 \cdot 0\end{array}$ & $\begin{array}{r}1 \cdot 0 \\
-14 \cdot 0 \\
12 \cdot 5\end{array}$ \\
\hline $\begin{array}{l}\text { Absorption cost: } \\
\text { amino acid } 2 \mathrm{ATP} / \mathrm{mol}+ \\
\text { glucose } 2 \text { ATP } / \mathrm{mol} \\
\left(P_{2}=1 \cdot 011 G-2 \cdot 01\right)\end{array}$ & $\begin{array}{l}\text { Base } 1 \\
\text { Base } 2 \\
\text { SDA }\end{array}$ & $\begin{array}{r}5.0 \S \\
125.4 \S \\
38 \cdot 1 \S\end{array}$ & $\begin{array}{r}3 \cdot 7 \\
61 \cdot 1 \\
26 \cdot 9\end{array}$ & $\begin{array}{r}3 \cdot 0 \\
25 \cdot 3 \\
20 \cdot 7\end{array}$ & $\begin{array}{r}2 \cdot 6 \\
2 \cdot 6 \\
16 \cdot 8\end{array}$ & $\begin{array}{r}2 \cdot 3 \\
-13 \cdot 2 \\
14 \cdot 0\end{array}$ \\
\hline $\begin{array}{l}\text { Absorption cost: } \\
\text { amino acid } 2 \mathrm{ATP} / \mathrm{mol}+ \\
\text { glucose } 0.5 \mathrm{ATP} / \mathrm{mol} \\
\left(P_{2}=1.010 G-2.54\right)\end{array}$ & $\begin{array}{l}\text { Base } 1 \\
\text { Base } 2 \\
\text { SDA }\end{array}$ & $\begin{array}{r}17 \cdot 4 \S \\
152 \cdot 1 \S \\
54 \cdot 5 \S\end{array}$ & $\begin{array}{l}12 \cdot 3 \S \\
74 \cdot 4 \S \\
37 \cdot 4 \S\end{array}$ & $\begin{array}{r}9 \cdot 5 \\
33 \cdot 3 \\
28 \cdot 3\end{array}$ & $\begin{array}{r}7.8 \\
7.8 \\
22.7\end{array}$ & $\begin{array}{r}6 \cdot 7 \\
-9 \cdot 4 \\
18 \cdot 9\end{array}$ \\
\hline $\begin{array}{l}\text { Absorption cost: } \\
\text { amino acid } 2 \mathrm{ATP} / \mathrm{mol}+ \\
\text { glucose } 2 \mathrm{ATP} / \mathrm{mol} \\
\left(P_{2}=1.012 G-1.31\right)\end{array}$ & $\begin{array}{l}\text { Base } 1 \\
\text { Base } 2 \\
\text { SDA }\end{array}$ & $\begin{array}{l}-7 \cdot 9 \| \\
97 \cdot 8 \\
21 \cdot 2\end{array}$ & $\begin{array}{r}-5 \cdot 7 \\
46 \cdot 4 \\
15 \cdot 4\end{array}$ & $\begin{array}{r}-4 \cdot 4 \\
16 \cdot 3 \\
12 \cdot 0\end{array}$ & $\begin{array}{r}-3 \cdot 5 \\
-3 \cdot 5 \\
9 \cdot 7\end{array}$ & $\begin{array}{c}-2 \cdot 9 \\
-17 \cdot 6 \\
8 \cdot 1\end{array}$ \\
\hline $\begin{array}{l}\text { Oxidation via } \\
\text { gluconeogenesis, } \\
\text { absorption cost: } \\
\text { amino acid } 2 \text { ATP } / \mathrm{mol}+ \\
\text { glucose } 0.5 \mathrm{ATP} / \mathrm{mol} \\
\left(P_{2}=1.008 G-3.32\right)\end{array}$ & $\begin{array}{l}\text { Base } 1 \\
\text { Base } 2 \\
\text { SDA }\end{array}$ & $\begin{array}{r}42 \cdot 3 \S \\
205 \cdot 7 \S \\
87 \cdot 4 \S\end{array}$ & $\begin{array}{l}27 \cdot 8 \S \\
98 \cdot 6 \S \\
56 \cdot 4 \S\end{array}$ & $\begin{array}{l}20.8 \S \\
47.0 \S \\
41.68\end{array}$ & $\begin{array}{l}16 \cdot 7 \\
16 \cdot 7 \\
32 \cdot 8\end{array}$ & $\begin{array}{r}14 \cdot 0 \\
-3 \cdot 2 \\
27 \cdot 1\end{array}$ \\
\hline $\begin{array}{l}\text { Oxidation via } \\
\text { gluconeogenesis, } \\
120 \% \text { urea synthesis, } \\
\text { absorption cost: } \\
\text { amino acid } 2 \text { ATP } / \mathrm{mol}+ \\
\text { glucose } 0.5 \text { ATP } / \mathrm{mol} \\
\left(P_{2}=1 \cdot 006 G-3.63\right)\end{array}$ & $\begin{array}{l}\text { Base } 1 \\
\text { Base } 2 \\
\text { SDA }\end{array}$ & $\begin{array}{r}55 \cdot 8 \S \\
234 \cdot 7 \S \\
105 \cdot 2 \S\end{array}$ & $\begin{array}{r}35.6 \S \\
110.6 \S \\
65.9 \S\end{array}$ & $\begin{array}{l}26 \cdot 2 \S \\
53 \cdot 5 \S \\
47 \cdot 9 \S\end{array}$ & $\begin{array}{l}20.98 \\
20.98 \\
37.5 \S\end{array}$ & $\begin{array}{c}17 \cdot 4 \| \\
-0 \cdot 3 \\
30 \cdot 1\end{array}$ \\
\hline $\begin{array}{l}\alpha \text {-Glycerophosphate } \\
\text { cycle; } \mathrm{NADH}_{\text {cyt }}=\mathrm{FADH}_{2} \\
\left(P_{2}=1.033 G-1.63\right)\end{array}$ & $\begin{array}{l}\text { Base } 1 \\
\text { Base } 2 \\
\text { SDA }\end{array}$ & $\begin{array}{r}-5 \cdot 0 \\
103 \cdot 9 \\
25 \cdot 0\end{array}$ & $\begin{array}{r}-4 \cdot 1 \\
48 \cdot 9 \\
17 \cdot 4\end{array}$ & $\begin{array}{r}-3 \cdot 6 \\
17 \cdot 3 \\
13 \cdot 0\end{array}$ & $\begin{array}{r}-3 \cdot 2 \\
-3 \cdot 2 \\
10 \cdot 2\end{array}$ & $\begin{array}{c}-3 \cdot 0 \\
-17 \cdot 6 \| \\
8 \cdot 2\end{array}$ \\
\hline $\begin{array}{l}\text { All food protein glutamate } \\
\text { and aspartate in amide form } \\
\left(P_{2}=1.08 G-1.86\right)\end{array}$ & Base 1 & $1 \cdot 0$ & 0.7 & 0.5 & $0 \cdot 4$ & $0 \cdot 3$ \\
\hline \multicolumn{7}{|c|}{ Protein oxidation via gluconeogenesis (differences from $P_{1}^{\prime}=1 \cdot 012 G-2 \cdot 29$ ): } \\
\hline $\begin{array}{l}\text { Absorption cost: } \\
\text { amino acid } 0.5 \mathrm{ATP} / \mathrm{mol}+ \\
\text { glucose } 2 \mathrm{ATP} / \mathrm{mol} \\
\left(P_{2}^{\prime}=0.999 \mathrm{G}-1.97\right)\end{array}$ & $\begin{array}{l}\text { Base } 1 \\
\text { Base } 2 \\
\text { SDA }\end{array}$ & $\begin{array}{r}-4 \cdot 6 \S \\
116 \cdot 3 \S \\
39 \cdot 4 \S\end{array}$ & $\begin{array}{r}-2 \cdot 9 \\
54 \cdot 8 \\
28 \cdot 1\end{array}$ & $\begin{array}{r}-1.9 \\
20.5 \\
22.0\end{array}$ & $\begin{array}{r}-1 \cdot 4 \\
-1 \cdot 4 \\
18 \cdot 1\end{array}$ & $\begin{array}{r}-1.0 \\
-16 \cdot 5 \\
15 \cdot 2\end{array}$ \\
\hline
\end{tabular}


Table 2. (cont.)

\begin{tabular}{|c|c|c|c|c|c|c|}
\hline Glucose energy $(G ; \mathrm{ATP} / \mathrm{MJ}) \ldots$ & & 7 & 9 & 11 & 13 & 15 \\
\hline $\begin{array}{l}\text { Absorption cost: } \\
\text { amino acid } 2 \text { ATP } / \mathrm{mol}+ \\
\text { glucose } 0.5 \text { ATP } / \mathrm{mol} \\
\left(P_{2}^{\prime}=1.008 G-3.32\right)\end{array}$ & $\begin{array}{l}\text { Base } 1 \\
\text { Base } 2 \\
\text { SDA }\end{array}$ & $\begin{array}{r}28.3 \S \\
190.8 \S \\
87.4 \S\end{array}$ & $\begin{array}{l}18 \cdot 5 \S \\
88 \cdot 9 \S \\
56 \cdot 4 \S\end{array}$ & $\begin{array}{l}13 \cdot 8 \S \\
39 \cdot 9 \S \\
41.6 \S\end{array}$ & $\begin{array}{l}11 \cdot 1 \| \\
11 \cdot 1 \\
33 \cdot 8\end{array}$ & $\begin{array}{r}9.2 \\
-7.9 \\
27.1\end{array}$ \\
\hline
\end{tabular}

Base $1=\left(\left(P_{1} / P_{2}\right)-1\right) \times 100 \%$ and Base $2=\left(\left(X / P_{2}\right)-1\right) \times 100 \%$, where $X=11.41$ when protein is oxidized directly (i.e. $P_{1}$ when $G=13$ ) and $X=10.87$ when protein is oxidized via gluconeogenesis (i.e. $P_{1}^{\prime}$ when $G=13$.

$\mathrm{SDA}=\left(\left(1 / P_{2}\right)-(1 / G)\right) \times G \times 100 \%$ when protein is oxidized directly and SDA $\left.=\left(1 / P_{2}^{\prime}\right)-(1 / G)\right) \times G \times 100 \%$ when protein is oxidized via gluconeogenesis.

Associated regression equations in parentheses.

* Only $80 \%$ of protein nitrogen incorporated into urea.

$\dagger 20 \%$ Urea recycled via ureolysis.

$\ddagger$ Energy costs refer to absorption of substrates from the gut which are estimated to be between 0.5 and $2 \cdot 0 \mathrm{ATP} / \mathrm{mol}$ amino acid or glucose.

$\S$ Associated with an SDA $>35 \%$, which seems improbable.

\| Limiting values discussed in the text.

Variations in the available biochemical energy in the 101 food proteins are also shown in Table 3. Four values are given which correspond to direct oxidation of protein and oxidation via glucose when the assumptions are such that the yield of ATP from glucose is low $(7 \mathrm{ATP} / \mathrm{MJ})$ and moderately high $(13 \mathrm{ATP} / \mathrm{MJ})$. These values are shown as percentage differences above $(+v e)$ or below $(-v e)$ the mean value for the biochemically available energy for the 101 food proteins. In general these differences are very small for proteins from foods in all the food groups and smaller than differences obtained when the energy values are expressed as MJ metabolizable energy/g protein (Table 3). Milk protein, while being energy rich on a $\mathrm{MJ} / \mathrm{g}$ protein basis, was additionally energy rich on an ATP/MJ metabolizable energy basis for each of the four conditions. In general, however, these findings indicate that most of the variation in biochemically available energy, as observed by Schulz (1975) and McGilvery (1979) who expressed energy values as ATP/g protein and ATP $/ g$ protein $\mathrm{N}$ respectively, is not due to variations in the efficiency of conversion of energy into ATP but to variation in the heats of combustion of the proteins/g protein or /g protein N. Coefficients of variation for the energy values for the 101 food proteins were determined and, when expressed as $\mathrm{MJ}$ metabolizable energy/g protein, $\mathrm{MJ}$ metabolizable energy/g amino acid $\mathrm{N}$ and $\mathrm{MJ}$ metabolizable energy/g food $\mathrm{N}$ were found to be 0.033 , 0.058 and 0.139 respectively. Similar coefficients were obtained when the denominators were held constant but with MJ replaced by ATP. However, coefficients of variation were much smaller for protein energy values, expressed as mol cytoplasmic ATP/MJ metabolizable energy; being 0.006 for protein oxidation directly and 0.007 via gluconeogenesis when the efficiency for glucose oxidation was $13 \mathrm{ATP} / \mathrm{MJ}$, and approximately 0.01 at a level of 7 ATP/MJ glucose.

Heats of combustion (gross energy) of beef fat, mutton fat, pork fat, olive oil and lard, based on the fatty acid composition data, were also not significantly different from values obtained by direct determination (Merrill \& Watt, 1955) showing a mean (and SD) difference of $0.5(1.8) \%$ between the two methods. For the 116 food fats examined the mean (and SD) gross energy was $39 \cdot 1(0 \cdot 4) \mathrm{kJ} / \mathrm{g}$ fat with a range of $37 \cdot 0-39 \cdot 2$ and a small coefficient of variation $(0 \cdot 02)$. Amongst the food groups, milk showed the greatest deviation from the mean, being $38.4 \mathrm{~kJ} / \mathrm{g}$ fat; this low value is due to a higher proportion of medium and short chain fatty acids. 


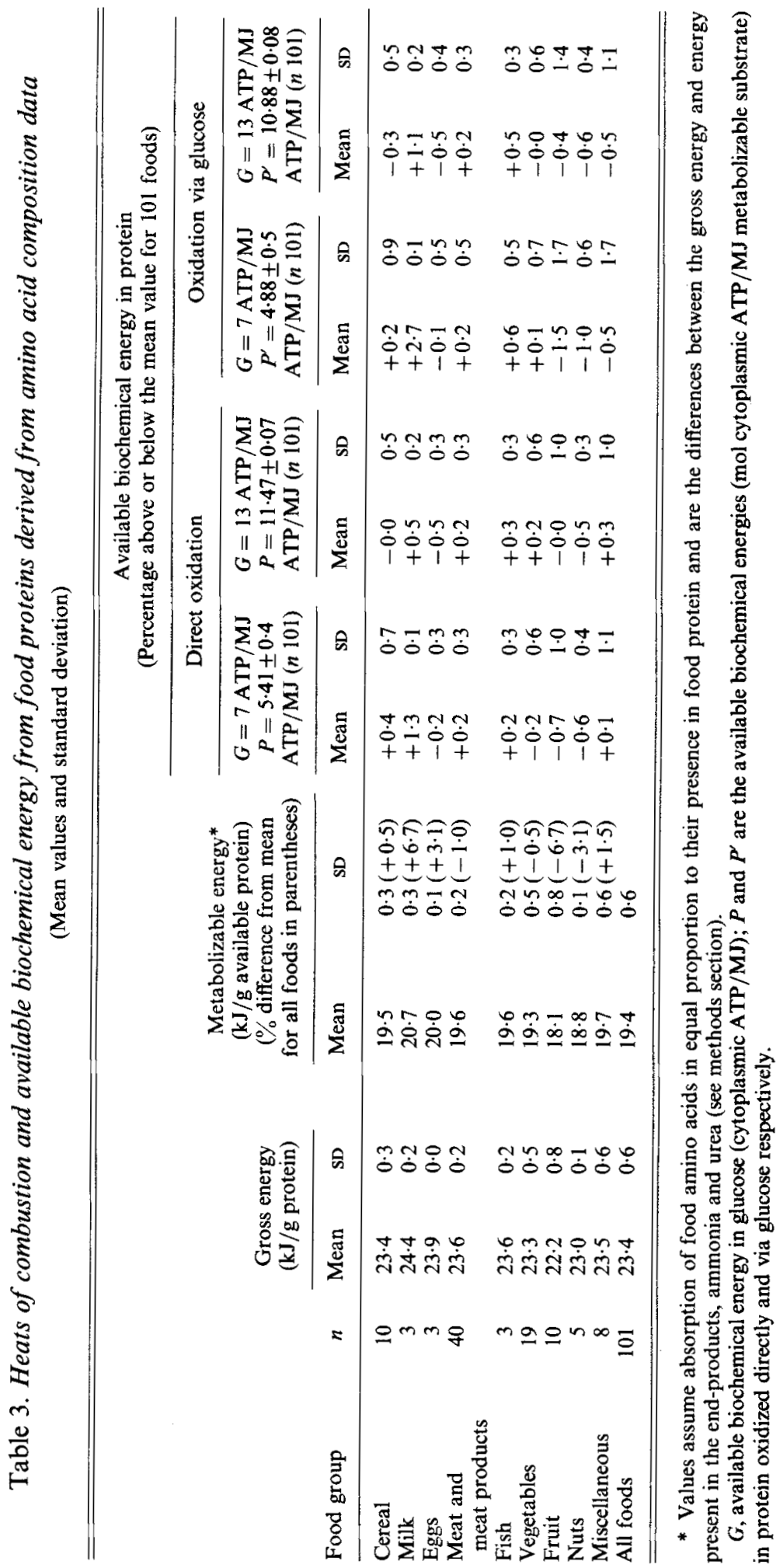


The available biochemical energy (ATP/MJ) varied little between one food fat and another, with a cv of 0.002 at the several levels of efficiency of oxidation. Thus, as for proteins, variation in energy value between fats appears to be mostly due to differences in heats of combustion rather than differences in the conversion of heat energy into ATP.

\section{Expression of food energy values}

There is presently no compelling requirement for revision of the Atwater factors to take account of differing efficiencies of biochemical oxidation of carbohydrates, fats and proteins. This position would be reversed, however, if it could be shown that the efficiency of mitochondrial oxidative phosphorylation in vivo was much lower than presently considered. Even so, simple factors would only be possible if oxidative efficiency was not variable both between and within individuals. Should either of such variations occur (Hegsted, 1974), relationships of the type presented here (see Fig. 1) would be necessary.

Variation in the efficiency of oxidation of different food proteins and fats is small by comparison with the variation in their heats of combustion. Therefore there should be no major dietetic improvements in protein:energy value or net dietary protein value (Miller $\&$ Payne, 1961) based on corrections for the conservation of energy during biochemical protein oxidation. The problem is mainly one of determining the heat of combustion of protein in foods. Estimations based on protein $\mathrm{N}$ in foods will inevitably give a wide range of values, as shown here, since it is precisely not the $\mathrm{N}$ that contains metabolizable energy. It is suggested that heats of combustion of food proteins can be accurately determined from amino acid composition data. Such data is now not difficult to obtain with sufficient accuracy and would overcome problems associated with completeness of protein extraction and purity from contamination with combustible materials.

The author is grateful to Mrs Susan A. Ring and Mr Barry J. Gordon for computer programming and to Dr David A. T. Southgate for helpful discussion of the manuscript.

\section{REFERENCES}

Adriaanse, N., Dekker, H. \& Coops, J. (1965). Recueil des Travaux Chimiques 84, 393-407.

Alexandre, A., Galliazzo, F. \& Lehninger, A. L. (1980). Journal of Biological Chemistry 255, 10721-10730.

Alexandre, A. \& Lehninger, A. L. (1979). Journal of Biological Chemistry 254, 11555-11560.

Alexandre, A., Reynafarje, B. \& Lehninger, A. L. (1978). Proceedings of the National Academy of Sciences of the USA 75, 5296-5300.

Al-Shawi, M. K. \& Brand, M. D. (1981). Biochemical Journal 200, 539-546.

Ashworth, A. (1969). Nature 233, 407-409.

Atkinson, D. E. (1971). Advances in Enzyme Regulation 9, 207-219.

Azzone, G. F., Pozzan, T., Di Virgillo, F. \& Miconi, V. (1978). In Frontiers of Biological Energetics, pp. 375-383

[P. L. Dutton, J. S. Leight and A. Scarpa, editors]. New York: Academic Press.

Ball, E. G. (1973). Energy Metabolism. Boston: Addison Wesley.

Brand, M. D., Harper, W. G., Nicholls, D. G. \& Ingledew, W. J. (1978). FEBS Letters 95, 125-129.

Brand, M. D., Reynafarje, B. \& Lehninger, A. L. (1976a). Proceedings of the National Academy of Sciences of the USA 73, 437-441.

Brand, M. D., Reynafarje, B. \& Lehninger, A. L. (1976b). Journal of Biological Chemistry 251, 5670-5679.

Chance, B. (1970). Proceedings of the National Academy of Sciences of the USA 66, 1175-1182.

Croft, L. R. (1973). Handbook of Protein Sequences. Oxford: Joynson-Bruvvers.

Flatt, J. P. (1977). In Recent Advances in Obesity Research: II, pp. 211-228 [G. A. Bray, editor]. London: Newman Publishing.

Flatt, J. P. (1980). Assessment of Energy Metabolism in Health and Disease, pp. $77-87$ [J. M. Kinney, editor]. Columbia, Ohio: Ross Laboratories.

Garrow, J. S. \& Hawes, S. F. (1972). British Journal of Nutrition 27, 211-219.

Gregg, V. A. \& Milligan, L. P. (1982). British Journal of Nutrition 48, 65-71.

Hegsted, D. M. (1974). Nutrition Reviews 32, 33-38.

Hinkle, P. C. (1981). In Chemiosmotic Proton Circuits in Biological Membranes, pp. 49-53 [V. P. Skulachev and

P. C. Hinkle, editors]. Boston: Addison Wesley.

Hinkle, P. C. \& Yu, M. L. (1979). Journal of Biological Chemistry 254, 2450-2455. 
Hogman, C. P. (1962). Handbook of Chemistry and Physics, 44th ed. Oxford: The Chemical Rubber Co.

Hommes, F. A. (1980). Nutrition and Metabolism 24, 110-113.

Hommes, F. A., Drost, Y. M., Geraets, W. X. M. \& Reijenga, M. A. A. (1975). Pediatric Research 9, 51-55.

Janz, G. J. (1958). Estimation of Thermodynamic Properties of Organic Compounds. New York: Academic Press.

Krebs, H. A. (1964). In Mammalian Protein Metabolism, vol. 1, pp. 125-176 [H. Munro and J. B. Allison, editors]. New York: Academic Press.

McGilvery, R. W. (1979). Biochemistry: a Functional Approach, 2nd ed. London: W. B. Saunders.

Matthews, P. M., Bland, J. L., Gadian, D. G. \& Radda, G. K. (1981). Biochemical and Biophysical Research Communications 103, 1052-1059.

Merrill, A. L. \& Watt, B. K. (1955). Energy Value of Foods. United States Department of Agriculture, Handbook 74.

Miller, D. S. \& Payne, P. R. (1961). British Journal of Nutrition 15, 11-19.

Millward, D. J., Garlick, P. J. \& Reeds, P. J. (1976). Proceedings of the Nutrition Society 35, 339-349.

Mitchell, P. \& Moyle, J. (1967a). Biochemical Journal 104, 588-600.

Mitchell, P. \& Moyle, J. (1967b). Biochemical Journal 105, 1147-1162.

Mitchell, P. \& Moyle, J. (1968). European Journal of Biochemistry 4, 530-539.

Mitchell, P. \& Moyle, J. (1969). European Journal of Biochemistry 7, 471-484.

Nicholls, D. G. (1976). FEBS Letters 61, 103-110.

Nicholls, D. G. (1982). Bioenergetics: an Introduction to the Chemiosmotic Theory. New York: Academic Press.

Nicholls, D. G. \& Lock, R. (1981). In Chemiosmotic Proton Circuits in Biological Membranes, pp 567-576 [V. P. Skulachev and P. C. Hinkle, editors]. Boston: Addison Wesley.

Papa, S., Capuano, F., Markert, M. \& Altamura, N. (1980a). FEBS Letters 111, 243-248.

Papa, S., Guerrieri, F., Lorusso, M., Izzo, G., Boffoli, D., Capuano, F., Capitano, N. \& Altamura, N. (1980 b), Biochemical Journal 192, 203-218.

Paul, A. A. \& Southgate, D. A. T. (1978). McCance \& Widdowson's 'The Composition of Foods', 4th ed. London: H. M. Stationery Office.

Pittet, P. H., Gygax, P. H. \& Jequier, E. (1974). British Journal of Nutrition 31, 343-349.

Ponomarev, V. V. (1962). Zhurnal Fizicheskoi Khimii 36, 1472-1476.

Pozzan, T., Di Virgilo, F., Bragadin, M., Miconi, V.\& Azzone, G. F. (1979 b). Proceedings of the National Academy of Sciences of the USA 76, 2123-2127.

Pozzan, T., Miconi, V., Di Virgilo, F. \& Azzone, G. F. (1979 a). Journal of Biological Chemistry 254, $10200-10205$.

Rawitscher, M., Wadso, I. \& Sturtevant, J. M. (1961). Journal of the American Chemical Society 83, $3180-3184$.

Reeds, P. J., Cadenhead, A., Fuller, M. F., Lobley, G. E. \& McDonald, J. D. (1980). British Journal of Nutrition 43, 445-455.

Reynafarje, B., Brand, M. D. \& Lehninger, A. L. (1976). Journal of Biological Chemistry 251, 7442-7451.

Rubner, M. (1902). In The Law of Energy Consumption in Nutrition, pp. 7-57 [R. J. T. Joy, editor]. Washington DC: U.S. Army Research Institute.

Rydstrom, J., Lee, C. P. \& Ernster, L. (1981). In Chemiosmotic Proton Circuits in Biological Membranes, pp. 483-504 [V. P. Skulachev and P. C. Hinkle, editors]. Boston: Addison Wesley.

Sallach, H. J. \& Fahien, L. A. (1969). In Metabolic Pathways, 3rd ed., vol. III, pp. 1-94. [D. Greenberg, editor]. New York: Academic Press.

Schulz, A. R. (1975). Journal of Nutrition 105, 200-207.

Schulz, A. R. (1977). British Journal of Nutrition 39, 235-254.

Shoubridge, E. A., Briggs, R. W. \& Radda, G. K. (1982). FEBS Letters 140, 288-292.

Skulachev, V. P. (1963). Proceedings of the 5th International Congress on Biochemistry, Moscow 5, $365-375$.

Sober, H. A. (1968). C.R.C. Handbook of Biochemistry and Selected Data for Molecular Biology. Oxford: The Chemical Rubber Co.

Stirling, J. L. \& Stock, M. J. (1968). Nature 220, 801-802.

Vercesi, A., Reynafarje, B. \& Lehninger, A. L. (1978). Journal of Biological Chemistry 253, 6379-6385.

Walser, M. (1981). In Nitrogen Metabolism in Man, pp. 229-246 [J. C. Waterlow and J. M. L. Stephens, editors]. London: Applied Science Publishers.

Waterlow, J. C., Garlick, P. J. \& Millward, D. J. (1978). Protein Turnover in Mammalian Tissues and in the Whole Body. Amsterdam: Elsevier North-Holland.

Webster, A. J. F., Lobley, G. E., Reeds, P. J. \& Puller, J. D. (1978). Proceedings of the Nutrition Society 37, 21 A. Whittaker, P. A. \& Danks, S. M. (1978). Mitochondria, Structure, Function and Assembly. London: Longman. Wilkström, M. K. F. \& Krab, K. (1979). Biochimica et Biophysica Acta 549, 177-222. 